DOI: https://doi.org/10.32839/2304-5809/2020-3-79-89

UDC 37.04

Shchypachova Daria

National Technical University of Ukraine

"Igor Sikorsky Kiev Polytechnic Institute"

\title{
PEDAGOGICAL CONDITIONS OF INDIVIDUALLY-ORIENTED FOREIGN LANGUAGE TRAINING FOR STUDENTS OF A TECHNICAL UNIVERSITY
}

Summary. The article deals with the research of pedagogical conditions of individually- oriented foreign language training for students of technical universities. The material contains a list of problems of individually-oriented foreign language training of students of higher education institutions in domestic and foreign theory and practice, as well as its criteria and pedagogical conditions. Modern science has accumulated rich experience in improving the organization of teaching foreign languages in higher education. However, the transition of the Ukrainian economy to market relations, the expansion of intercultural ties and communications in this regard, the spread of globalization processes have generated a higher level of demand for knowledge of foreign languages. Fundamental transformations in society, updating the goals and content of education have created real makings for new technologies for teaching foreign languages. One of the possible effective approaches to teaching students is individually oriented, which is directed against the standardization of the educational process, which still prevails in the traditional higher education system, where the factor of individuality is not sufficiently taken into account. As the main conditions for the implementation of individualized foreign language training for students of a technical university, two components were identified: the content of training students for mastering a professionally-oriented English language and the process of its organization. We have identified the criteria for individually-oriented foreign-language training of students of a technical university: the assimilation by students of a significant amount of material in a short time; language competence; the passion shown by students in mastering a foreign language; developing a culture of mastering professionally-oriented English; active use of the new for a deeper assimilation of the past.

Keywords: individually-oriented training, vocational training methods, information technologies, teaching principles and methods, "dialogue of cultures", professional competence, pedagogical conditions, individuallyoriented training criteria, foreign language proficiency.

Щипачова Д.С.

Національний технічний університет України «Київський політехнічний інститут імені Ігоря Сікорського»

\section{ПЕДАГОГІЧНІ УМОВИ ІНДИВІДУАЛЬНО-ОРІЕНТОВАНОЇ ІНШОМОВНОЇ ПІДГОТОВКИ СТУДЕНТІВ ТЕХНІЧНОГО ВУЗУ}

Анотація. Стаття присвячена дослідженню педагогічних умов індивідуально-орієнтованої іншомовної підготовки студентів технічного ВНЗ. Матеріал містить перелік проблем індивідуально-орієнтованої іншомовної підготовки студентів ВНЗ у вітчизняній та зарубіжній теорії та практищі, а також її критеріїв та педагогічних умов. Сучасною наукою накопичено багатий досвід щодо вдосконалення організації навчання іноземним мовам у вищій школі. Однак перехід української економіки на ринкові відносини, розширення в зв'язку з цим міжкультурних зв'язків та комунікацій, поширення процесів глобалізації породили більш високий рівень затребуваності знання іноземних мов. Корінні перетворення в суспільстві, оновлення цілей і змісту освіти створили реальні передумови для нових технологій навчання іноземним мовам. Одним з можливих ефективних підходів до навчання студентів $є$ індивідуально-оріентований, який спрямований проти все ще пануючої в традищійній системі вищої освіти стандартизації навчального процесу, де фрактор індивідуальності враховуеться недостатньо. Моделювання педагогічного процесу в світлі індивідуально-орієнтованого підходу дозволяє виділити основні педагогічні умови і їх можливості для підвищення особистої і професійної значущості вивчення іноземної мови студентами. В якості основних умов реалізації індивідуалізованої іншомовної підготовки студентів технічного вузу були виявлені два компоненти: зміст підготовки студентів до засвоєння профеесійно-орієнтованої англійської мови і процес ії організації. В процесі дослідження були виділені критерії індивідуально-орієнтованої іншомовної підготовки студентів технічного вузу: засвоєння студентами значної кількості матеріалу в стислі терміни; мовна компетентність; захопленість, яку проявляють студенти в оволодінні іноземною мовою; розвиток культури оволодіння професійно-оріентованою англійською мовою; активне використання нового для більш глибокого засвоєння пройденого. Були визначені рівні володіння студентами іноземною мовою.

Ключові слова: індивідуально-орієнтована підготовка, методики профресійного навчання, інформаційні технології, принципи та методи навчання, «діалог культур», професійна компетентність, педагогічні умови, критерії індивідуально-орієнтованої підготовки, рівні володіння іноземною мовою.

Droblem statement. The main task of educa-

1 tion in the 21st century is to educate a person with a humanistic attitude, able to navigate in difficult socio-cultural circumstances, actively realizing his personal potential on the basis of mutual understanding, cooperation and tolerance. In accordance with humanistic principles, a higher vocational school should direct its efforts towards the formation of a holistic personality of a citizen, a cre- ator, a person of morality and culture (V.S. Bibler, Y.V. Bondarevskaya, I.A. Zimnyaya, etc.) [1; 3].

Given the awareness of the need to move on to the path of stable development of civilization, the imperative of the "survival" of mankind, the restructuring of the country's economy, technological development, and the prioritization of scientific and intellectually intensive technologies, specialists who have graduated from a technical universi- 
ty become key figures in the socio-economic sphere of society [3].

Competition in the intellectual labor market poses challenges for technical universities to meet market demand for specialists of a certain level and quality of training. Today, we need well-rounded people with interpersonal skills, who do not need constant leadership, are able to act in conditions of uncertainty, and conduct an independent search for solutions to complex problems. Of course, the industry needs professionals, but a real professional, not sensitive to others, not able to work in a group, not capable of sharing knowledge, is inefficient.

The training of technical university students for the complex technocratic processes of modern industrial production is essentially a subsystem of vocational education in this subject area and is carried out on the basis of the laws of professional pedagogy, professional activity, didactic characteristics of these categories, as well as personality formation based on the laws of vocational training.

The process of teaching a foreign language at the industry level, as well as the entire process of professional education, is changing due to the intensive inclusion of new educational, information technologies. In this connection, the principles and teaching methods are changing qualitatively. The specifics of foreign language training for students of a technical university is the active transition to new modern technologies. Traditional methods that have been tested and recognized over many years are being replaced by new modern technologies, but this is not always done reasonably and effectively. The integration of traditional methods of vocational training and new approaches to teaching foreign languages involves the parallel coexistence and smooth interaction of these methods, since both recognized and new technologies imply the achievement of the same goals: an effective and high-quality level of knowledge and knowledge of a foreign language $[1 ; 3 ; 5]$.

The necessary level of knowledge of a foreign language allows you to meet international standards, improve the quality of training of future specialists.

Today, modern education is becoming increasingly open to international cooperation. Under the influence of major political and economic changes taking place in the world, education is becoming more and more global in nature. At the university level, multilateral interstate relations, major targeted and comprehensive international educational projects and programs are being implemented. In high school there is a process of internationalization.

The essence of the current stage of renewal of education is the transition to the ideas and principles of a personality-oriented developing education. For a modern society, mastering by a specialist of various knowledge is obviously not enough. Of great importance is the development of the ability to independently acquire knowledge and put them into practice. And this is possible only when changing priorities in education - from assimilation of ready-made knowledge during training sessions to the independent cognitive activities of each student, taking into account its features and capabilities. A personality-oriented education is focused not on the formation of a personality with desired properties, but on the creation of conditions for the full manifestation and development of a person's personal functions.

Recent research and publications. The problem of an individual approach in pedagogy is deeply covered in the works of V.I. Zagvyazinskyi, A.A. Kirsanova, A.A. Budarnoy, M.A. Danilov, Y.S. Rabunskyi, I. Unt, and others. A number of aspects of the problem are considered in various contexts: in the intensification of education (M.I. Makhmutov, M.A. Danilov, B.P. Yesipov, I.T. Ogorodnikov, etc.); in the optimization of the cognitive process (Yu.K. Babanskyi); in the development of theoretical thinking (D.B. Elkonin and others); in problem teaching (M.I. Makhmutov, I.Ya. Lerner, etc.); in programmed instruction (Yu.N. Kulyutkin, G.S. Sukhobskaya, etc.); in modular training (T.I. Shamova); in an individual style of activity (Ye.A. Klimov, B.S. Merlin); in the phased formation of mental actions (P.Ya. Halperin, N.F. Talyzina); in cognitive interests (G.I. Bozhovich, G.I. Shchukina) [2; 3; 4; 5].

The purpose of the study is to increase the effectiveness of the process of teaching foreign languages to students of a technical university.

\section{Research objectives:}

- to study the problem of individually-oriented foreign language training of university students in domestic and foreign theory and practice;

- identify the criteria for English language proficiency and pedagogical conditions of individually-oriented foreign language training for students of a technical university.

Presentation of the main material. Modern science has accumulated rich experience in improving the organization of teaching foreign languages in higher education. However, the transition of the Ukrainian economy to market relations, the expansion of intercultural ties and communications in this regard, the spread of globalization processes have generated a higher level of demand for knowledge of foreign languages. Fundamental transformations in society, updating the goals and content of education have created real makings for new technologies for teaching foreign languages. One of the possible effective approaches to teaching students is individually oriented, which is directed against the standardization of the educational process, which still prevails in the traditional higher education system, where the factor of individuality is not sufficiently taken into account.

The main direction that defines the learning strategy in general and the strategy of teaching foreign languages in particular is the cultural and historical paradigm, which is implemented in a personality-oriented approach to education and training. The basic educational principles are dialogic ("dialogue of cultures"), humanitarian, humanistic, axiological.

The realization of the cultural and educational potential of a foreign language in a technical university has the goal of developing a person, revealing his inner capabilities and abilities by means of this subject. Today in technical education there is a review of the goals, content and technology of teaching foreign languages, it provides solutions to the issues of increasing motivation for learning foreign languages, strengthening the material and technical base and staffing, attracting specialists of all profiles who are fluent in a foreign language to technical universities, developing a multi-level personality oriented foreign language training of students and the formation in the university of an active information and educational language environment, etc. The main target in the state educational standard is the practical knowledge of a foreign language as a means of intercultural communication. The formation in the system of technical education of a high level of informa- 
tion culture is a necessary requirement for ensuring the productivity of engineering activities.

The purpose of vocational training in a technical university is not only and not so much in training a competent specialist, but in orienting education to internal personal growth, revealing the creative personality of a future specialist.

The professionalization of higher technical education is aimed at training a new type of professional specialist, a carrier of holistic scientific and technical activity, distinguished by global thinking, encyclopedic knowledge, aristocratic spirit, capable of creative work at all stages of the life cycle. And a foreign language is an important means of achieving this goal. Today, knowledge of a foreign language and professional competence are becoming important factors in the training of future specialists in technical universities.

Given the general trends in the development of teaching technologies, we have justified the leading patterns of an individually-oriented approach. The following didactic principles of individualized teaching English to students were highlighted: taking into account the individual characteristics and capabilities of students, scientificality, accessibility, consistency, the relationship of theoretical learning with practical activities, consciousness, independence and activation of the learner, strength, development of students' thinking.

Modeling the pedagogical process in the condition of an individually-oriented approach allows us to highlight the main pedagogical conditions and their possibilities for increasing the personal and professional significance of students studying a foreign language. As the main conditions for the implementation of individualized foreign language training for students of a technical university, two components were identified: the content of training students for mastering a professionally-oriented English language and the process of its organization $[2 ; 5]$.

Content component: the content of training, considered as a means of personal, professional development of a future specialist, involves a harmonious combination of theoretical and practical aspects of the content of training, the use of intersubject communications, the creation of multiple problems that activate students; professionally significant information should be laid in the content of foreign language training at a university; in the lessons of a foreign language it is necessary to realize the rich potential of culture, that is, to carry out a "dialogue of cultures"; in the process of mastering in- dividually-oriented English, the teacher must use the wide possibilities of "open" learning.

Organizational component: the introduction of innovative forms and methods of training; the implementation of "educational communication"; monitoring and checking students' knowledge as the most important requirement for organizing the process of training foreign students of a technical university.

We have identified the criteria for individually-oriented foreign-language training of students of a technical university: the assimilation by students of a significant amount of material in a short time; language competence; the passion shown by students in mastering a foreign language; developing a culture of mastering professionally-oriented English; active use of the new for a deeper assimilation of the past $[2 ; 4]$.

Conclusion. An individually-oriented approach to teaching students of a technical university is implemented in an individually-oriented model of foreign language training, which is considered as a designation of a teacher's plan or action plan in the implementation of the educational process, the basis of which is the transformative activity of students organized by the teacher. The main goal of individually-oriented foreign language training is to promote the development and establishment of the creative personality of a future specialist. Moreover, the training is based on the technology of activating and intensifying the activities of students, personality-oriented developing learning, dialogic ("dialogue of cultures") and sign-contextual approaches and involves taking into account the individual characteristics, capabilities, interests of each student.

The study proved the higher efficiency of the proposed model of individually-oriented foreign language training for students of a technical university in comparison with the traditional methodology of teaching a foreign language. The methods, techniques and means used really contributed to the expansion of the need-motivational sphere of studying professional English, the increase of knowledge, abilities and skills of students.

All the results prove the correctness of the choice of hypothetical issues, the correctness of establishing the pedagogical conditions of individually-oriented foreign-language training of students of a technical university for mastering a professionally-oriented English language and the possibility of their practical implementation.

\section{References:}

1. Bodaliev, A.A. (2002). Psihologiya obshcheniya [Communication Psychology]. Moscow: MPSI. (in Russian)

2. Doronkina, N.E., \& Ivasiuk, O.V. (2015). Students' individual characteristics consideration in teaching English. Scientific Journal "Advanced education", vol. 4, pp. 18-21.

3. Foundation for advancement of science (2002). The capability of communicating in a meaningful and productive manner, $26 \mathrm{p}$.

4. Hordieeva, N.N. (2002). Individualizaciya obucheniya [Individualisation of Learning]. Scientific Journal "Pedagogy", vol. 2, pp. 32-38.

5. Shchypachova, D.S. (2016). Differentiated approach in foreign language training of students of non-linguistic specialties. Scientific Journal of International Humanitarian University, vol. 20(2), pp. 102-105.

\section{Список літератури:}

1. Бодалев А.А. Психология общения. Москва : МПСИ, 2002. 320 с.

2. Doronkina N.E., Ivasiuk O.V. Students' individual characteristics consideration in teaching English. Scientific Journal "Advanced education". 2015. Vol. 4, pp. 18-21.

3. Hordieeva N.N. Individualisation of Learning. Scientific Journal "Pedagogy”. 2002. Vol. 2, pp. 32-38.

4. Shchypachova D.S. Differentiated approach in foreign language training of students of non-linguistic specialties. Scientific Journal of International Humanitarian University. 2016. Vol. 20(2), pp. 102-105.

5. The capability of communicating in a meaningful and productive manner. Foundation for advancement of science, $2002.26 \mathrm{p}$. 